\title{
PENGEMBANGAN DAERAH PESISIR DENGAN PEMBERDAYAAN MASYARAKAT NELAYAN DI KAWASAN PESISIR KABUPATEN BADUNG
}

\author{
Putu Agus Prayogi ${ }^{1}$, Ni Luh Komang Julyanti Paramita Sari ${ }^{2}$ \\ STIPAR Triatma Jaya ${ }^{1}$, STIE Triatma Mulya ${ }^{2}$ \\ agus.prayogi@triatma-mapindo.ac.id ${ }^{1}$, julyanti.paramita@gmail.com²
}

\begin{abstract}
Development of coastal tourism by empowering fishing communities in Badung is one form of development that aims to make fishing communities as local genius of coastal areas. It can directly give benefit to the development of tourism in this area. The model of empowerment of fishing communities which is developed in coastal tourism uses several strategies, namely traditional, direct action, and transformation. The development of coastal tourism with the empowerment of fishing communities is expected to have a positive impact on the economy and socio-culture of fishing communities. Economic impacts can be seen from the direct opinions received by fishing communities from their direct involvement in the development of tourism villages. Whereas the socio-cultural impacts that are felt by the fishing community derives from direct interaction with tourists, such as the fishing community knowing the habits of tourists, using technology and the ability to communicate using foreign languages.
\end{abstract}

Key words : tourism villages, empowerment, economy and socio-culture

\begin{abstract}
Abstrak
Pengembangan wisata pantai dengan memberdayakan masyarakat nelayan di Badung merupakan salah satu bentuk pengembangan yang bertujuan menjadikan masyarakat nelayan sebagai kearifan lokal daerah pesisir. Ini bisa langsung memberi manfaat bagi pengembangan pariwisata di daerah ini. Model pemberdayaan masyarakat nelayan yang dikembangkan dalam wisata pantai menggunakan beberapa strategi, yaitu tradisional, aksi langsung, dan transformasi. Pengembangan wisata pantai dengan pemberdayaan masyarakat nelayan diharapkan memiliki dampak positif terhadap ekonomi dan sosial budaya masyarakat nelayan. Dampak ekonomi dapat dilihat dari pendapat langsung yang diterima oleh masyarakat nelayan dari keterlibatan langsung mereka dalam pengembangan desa wisata. Sedangkan dampak sosial budaya yang dirasakan oleh komunitas nelayan berasal dari interaksi langsung dengan wisatawan, seperti komunitas nelayan yang mengetahui kebiasaan wisatawan, menggunakan teknologi dan kemampuan berkomunikasi menggunakan bahasa asing.
\end{abstract}

Kata kunci: desa wisata, pemberdayaan, ekonomi dan sosial budaya

\section{PENDAHULUAN}

Sebagai salah satu Negara tujuan wisata, Indonesia memiliki kawasan pesisir yang kaya akan sumber daya alamnya dan memilik potensi untuk dikembangkan menjadi objek pariwisata bahari. Indonesia merupakan negara kepulauan terbesar di dunia, Indonesia memiliki 17.499 pulau dari Sabang hingga Merauke. Luas total wilayah 
Indonesia adalah 7,81 juta $\mathrm{km}^{2}$ yang terdiri dari 2,01 juta $\mathrm{km}^{2}$ daratan, 3,25 juta $\mathrm{km}^{2}$ lautan, dan 2,55 juta $\mathrm{km}^{2}$ Zona Ekonomi Eksklusif (ZEE). Indonesia merupakan suatu Negara dengan luas perairan lebih besar daripada luas daratan, maka dari itu Indonesia disebut sebagai Negara Maritim. Dengan kondisi seperti ini, Indonesia sangat berpotensi untuk mengembangkan pariwisata dengan memanfaatkan potensi yang dimiliki oleh daerah pesisir di sepanjang garis pantai. Namun potensi ini baru dapat terwujud apabila sumber daya yang ada dapat dikembangkan secara optimal. Pengembangan kawasan pesisir untuk keperluan industri pariwisata di Indonesia cendrung mengalami peningkatan dari tahun ke tahun. Tidak hanya dikembangkan sebagai daerah tujuan wisata namun juga dikembangkan sebagai daerah penyedia sarana prasarana bagi wisatawan. Selain memberikan keuntungan dalam pemanfaatan potensi alam secara berkelanjutan, pengembangan kawasan pesisir untuk kegiatan wisata juga berpotensi untuk meningkatkan perekonomian masyarakat pesisir yang sebagian besar berprofesi sebagai nelayan. Dalam berwisata sudah tentu wisatawan tersebut ingin dilayani serta mendapatkan akomodasi yang layak sesuai dengan apa yang diharapkan wisatawan masing-masing (Anggayana \& Sari, 2018). Peningkatan ini sudah tentu ditunjang oleh pelayanan yang baik, dalam pelayanan tersebut, fasilitas dan kualitas pelayanan menjadi ujung tombak dalam hal pemberian kesan baik terhadap pelayanan (Anggayana \& Sari, 2018).

Sebagai salah satu daerah tujuan wisata di Indonesia, Bali memiliki daya tarik tersendiri di benak wisatawan di seluruh dunia, dimana nama Bali merupakan brand sebagai destinasi wisata yang unik dan membuat wisatawan datang ke Bali (Hobart, 2015). Dengan berbagai potensi wisata yang dimiliki sangatlah wajar Bali menjadi salah satu tujuan utama wisatawan asing yang berkunjung ke Indonesia. Selain potensi budaya yang dimiliki oleh Bali sebagai salah satu daerah tujuan wisata, potensi alam yang dimiliki juga menjadikan Bali sangat diminati oleh wisatawa. Mulai dari terasering sawah, daerah pegunungan, aliran sungai sampai dengan daerah pesisir memiliki potensi alam yang sangat menarik untuk dikunjungi oleh para wisatawan. Bahkan beberapa daerah pesisir seperti kawasan pesisir pantai Kuta dan Nusa Dua telah menjadi brand image pariwisata di Bali. Hampir seluruh Kabupaten di Bali kecuali Kabupaten Bangli memiliki kawasan pesisir yang diminati oleh para wisatawan sebagai tempat untuk mereka melakukan aktifitas wisata, mulai dari wisata selam, selancar ataupun aktifitas wisata bahari lainnya. Dengan daya tarik yang dimiliki menjadikan daerah-daerah pesisir di Bali mengalami perkembangan yang sangat pesat terutama dari perkembangan fasilitasfasilitas untuk kepentingan pengembangan kepariwisataan. Sejalan dengan sumber daya manusia diperlukan penguasaan bahasa Inggris, English exist as a global language, therefore English is widely regarded as global language (Anggayana, Nitiasih, \& Budasi, 2016). English is used in the early stages of major social and economic transition (Anggayana, Nitiasih, \& Budasi, 2016).

Sebagai salah satu Kabupaten di Provinsi Bali, Kabupaten Badung adalah salah satu Kabupaten di Provinsi Bali yang Pajak Hotel dan Restoran (PHR) mencapai lebih dari $50 \%$ dari total Pendapatan Asli Daerah (PAD) Kabupaten di tahun 2017 (www.bappeda.badungkab.go.id). Data ini menunjukan bahwa Kabupaten Badung sangat bergantung pada sektor Pariwisata didalam menggerakan sektor perekonomiannya.

Sebagian besar daya tarik wisata di Kabupaten Badung lebih banyak berada di kawasan pesisir (21 daya tarik wisata), seperti pada Tabel 1 berikut : 


\section{Tabel 1}

\section{Daya Tarik Wisata di Kabupaten Badung}

\begin{tabular}{|c|c|c|c|}
\hline No & $\begin{array}{l}\text { Daya Tarik } \\
\text { Wisata }\end{array}$ & $\begin{array}{l}\text { Lokasi (Desa, } \\
\text { Kecamatan) }\end{array}$ & $\begin{array}{l}\text { Area } \\
\text { Geografis }\end{array}$ \\
\hline 1 & $\begin{array}{l}\text { Kawasan Luar } \\
\text { Pura Uluwatu }\end{array}$ & $\begin{array}{l}\text { Pecatu, Kuta } \\
\text { Selatan }\end{array}$ & Pesisir \\
\hline 2 & Pantai Suluban & $\begin{array}{l}\text { Pecatu, Kuta } \\
\text { Selatan }\end{array}$ & Pesisir \\
\hline 3 & $\begin{array}{l}\text { Pantai Nyang- } \\
\text { nyang }\end{array}$ & $\begin{array}{l}\text { Pecatu, Kuta } \\
\text { Selatan }\end{array}$ & Pesisir \\
\hline 4 & $\begin{array}{l}\text { Pantai Padang- } \\
\text { padang }\end{array}$ & $\begin{array}{l}\text { Pecatu, Kuta } \\
\text { Selatan }\end{array}$ & Pesisir \\
\hline 5 & $\begin{array}{l}\text { Pantai Labuan } \\
\text { Sait }\end{array}$ & $\begin{array}{l}\text { Pecatu, Kuta } \\
\text { Selatan }\end{array}$ & Pesisir \\
\hline 6 & $\begin{array}{l}\text { Pantai Batu } \\
\text { Pageh }\end{array}$ & $\begin{array}{l}\text { Ungasan, Kuta } \\
\text { Selatan }\end{array}$ & Pesisir \\
\hline 7 & Pantai Samuh & $\begin{array}{l}\text { Benoa, Kuta } \\
\text { Selatan }\end{array}$ & Pesisir \\
\hline 8 & $\begin{array}{l}\text { Pantai Geger } \\
\text { Sawangan }\end{array}$ & $\begin{array}{l}\text { Benoa, Kuta } \\
\text { Selatan }\end{array}$ & Pesisir \\
\hline 9 & $\begin{array}{l}\text { Pantai Nusa } \\
\text { Dua }\end{array}$ & $\begin{array}{l}\text { Benoa, Kuta } \\
\text { Selatan }\end{array}$ & Pesisir \\
\hline 10 & $\begin{array}{l}\text { Pantai Tanjung } \\
\text { Benoa }\end{array}$ & $\begin{array}{l}\text { Tanjung Benoa, } \\
\text { Kuta Selatan }\end{array}$ & Pesisir \\
\hline 11 & $\begin{array}{l}\text { Pelestarian } \\
\text { Penyu Deluang }\end{array}$ & $\begin{array}{l}\text { Tanjung Benoa } \\
\text { Sari, Kuta Selatan }\end{array}$ & Pesisir \\
\hline 12 & $\begin{array}{l}\text { Taman Rekreasi } \\
\text { Hutan Bakau }\end{array}$ & $\begin{array}{l}\text { Jimbaran, Kuta } \\
\text { Selatan }\end{array}$ & Pesisir \\
\hline 13 & Pantai Jimbaran & $\begin{array}{l}\text { Jibaran, Kuta } \\
\text { Selatan }\end{array}$ & Pesisir \\
\hline 14 & $\begin{array}{l}\text { Garuda Wisnu } \\
\text { Kencana }\end{array}$ & $\begin{array}{l}\text { Tuban, Kuta } \\
\text { Selatan }\end{array}$ & $\begin{array}{l}\text { Bukan } \\
\text { Pesisir }\end{array}$ \\
\hline 15 & $\begin{array}{l}\text { Pantai } \\
\text { Kedonganan }\end{array}$ & Kedonganan, Kuta & Pesisir \\
\hline 16 & Pantai Kuta & Kuta & Pesisir \\
\hline 17 & Waterboom & Kuta & Pesisir \\
\hline 18 & Pantai Legian & $\begin{array}{l}\text { Legian, Kuta } \\
\text { Selatan }\end{array}$ & Pesisir \\
\hline 19 & $\begin{array}{l}\text { Pantai Peti } \\
\text { Tenget }\end{array}$ & Kerobokan & Pesisir \\
\hline 20 & Pantai Canggu & $\begin{array}{l}\text { Canggu, Kuta } \\
\text { Utara }\end{array}$ & Pesisir \\
\hline 21 & Pantai Seseh & $\begin{array}{l}\text { Munggu, Kuta } \\
\text { Utara }\end{array}$ & Pesisir \\
\hline 22 & Pura Sada & Kapal, Mengwi & $\begin{array}{l}\text { Bukan } \\
\text { Pesisir }\end{array}$ \\
\hline 23 & $\begin{array}{l}\text { Kawasan Luar } \\
\text { Pura Taman } \\
\text { Ayun }\end{array}$ & Mengwi, Mengwi & $\begin{array}{l}\text { Bukan } \\
\text { Pesisir }\end{array}$ \\
\hline 24 & $\begin{array}{l}\text { Desa Wisata } \\
\text { Baha }\end{array}$ & Baha, Mengwi & $\begin{array}{l}\text { Bukan } \\
\text { Pesisir }\end{array}$ \\
\hline 25 & $\begin{array}{l}\text { Bumi } \\
\text { Perkemahan } \\
\text { Blahkiuh }\end{array}$ & $\begin{array}{l}\text { Blahkiuh, Abian } \\
\text { Semal }\end{array}$ & $\begin{array}{l}\text { Bukan } \\
\text { Pesisir }\end{array}$ \\
\hline 26 & $\begin{array}{l}\text { Alas Pala } \\
\text { Sangeh }\end{array}$ & $\begin{array}{l}\text { Sangeh, Abian } \\
\text { Semal }\end{array}$ & $\begin{array}{l}\text { Bukan } \\
\text { Pesisir }\end{array}$ \\
\hline 27 & Tanah Wuk & $\begin{array}{l}\text { Sangeh, Abian } \\
\text { Semal }\end{array}$ & $\begin{array}{l}\text { Bukan } \\
\text { Pesisir }\end{array}$ \\
\hline 28 & $\begin{array}{l}\text { Air Terjun } \\
\text { Nungnung }\end{array}$ & Pelaga, Petang & $\begin{array}{l}\text { Bukan } \\
\text { Pesisir }\end{array}$ \\
\hline 29 & $\begin{array}{l}\text { Wisata Agro } \\
\text { Pelaga }\end{array}$ & Pelaga, Petang & $\begin{array}{l}\text { Bukan } \\
\text { Pesisir }\end{array}$ \\
\hline 30 & $\begin{array}{l}\text { Kawasan Luar } \\
\text { Pura Puncak } \\
\text { Tedung Petang }\end{array}$ & Pelaga, Petang & $\begin{array}{l}\text { Bukan } \\
\text { Pesisir }\end{array}$ \\
\hline
\end{tabular}

\begin{tabular}{|c|l|l|l|}
\hline No & $\begin{array}{l}\text { Daya Tarik } \\
\text { Wisata }\end{array}$ & $\begin{array}{l}\text { Lokasi (Desa, } \\
\text { Kecamatan) }\end{array}$ & $\begin{array}{l}\text { Area } \\
\text { Geografis }\end{array}$ \\
\hline 31 & Pantai Berawa & $\begin{array}{l}\text { Tibu Beneng, Kuta } \\
\text { Utara }\end{array}$ & Pesisir \\
\hline 32 & $\begin{array}{l}\text { Kawasan Pura } \\
\text { Keraban Langit }\end{array}$ & Sading, Mengwi & $\begin{array}{l}\text { Bukan } \\
\text { Pesisir }\end{array}$ \\
\hline 33 & $\begin{array}{l}\text { Monumen } \\
\text { Tragedi } \\
\text { Kemanusiaan }\end{array}$ & Legian, Kuta & Pesisir \\
\hline
\end{tabular}

Sumber : Dinas Pariwisata Daerah Badung, 2017

Berdasarkan Tabel 1 diatas dapat dilihat bahwa kawasan pesisir menjadi sentra pengembangan Pariwisata di Kabupaten Badung. Hal ini tidak mengherankan mengingat sebagian besar kawasan pesisir di Kabupaten Badung memiliki daya tarik tersendiri bagi para wisatawan. Beberapa kawasan pesisir di Kabupaten Badung seperti pantai Kuta, pantai Nusa Dua merupakan kawasan pesisir yang menjadi primadona bagi para wisatawan untuk berlibur. Namun pengembangan kawasan pesisir sebagai kawasan wisata di Kabupaten Badung memberikan dampak terhadap kehidupan masyarakat nelayan. Hampir sebagian besar aktifitas masyarakat nelayan terdesak sebagai akibat pengembangan kawasan pesisir sebagai kawasan wisata.

Penelitian ini sangat perlu dilakukan mengingat eksistensi nelayan yang semakin terdesak dengan pengembangan kepariwisataan di daerah pesisir. Penelitian ini bertujuan agar pengembangan pariwisata di daerah pesisir bisa bersinergi dengan kehidupan masyarakat nelayan, sehingga mampu melestarikan kehidupan masyarakat nelayan sekaligus bisa dijadikan sebagai salah satu atraksi atau daya tarik wisata budaya di kawasan pesisir.

Berdasarkan uraian di atas, maka dapat dirumuskan permasalahan dalam penelitian ini, sebagai berikut :

1. Bagaimanakah bentuk pemberdayaan masyarakat nelayan dalam 
pengembangan daerah pesisir dengan pemberdayaan masyarakat nelayan di Kawasan Pesisir Kabupaten Badung?

2. Bagaimanakah dampak ekonomi yang ditimbulkan bagi masyarakat nelayan didalam pengembangan kawasan pesisir dengan pemberdayaan masyarakat nelayan di Kabupaten Badung?

3. Bagaimanakah dampak sosial budaya yang ditimbulkan bagi masyarakat nelayan didalam pengembangan daerah pesisir dengan pemberdayaan masyarakat nelayan di Kabupaten Badung ?

\section{TINJAUAN PUSTAKA}

\section{Tinjauan Empiris}

Dalam penelitian Santi (2017) mengenai kajian wisata bahari terhadap kesejahteraan masyarakat di kawasan pesisir di jelaskan bahwa pengembangan wisata bahari di daerah pesisir telah mampu meningkatkan kesejahteraan masyarakat disekitar pesisir. Terdapat tiga strategi dalam alternatif kebijakan pengembangannya yaitu pengelolaan wisata bahari yang berkelanjutan, mengembangkan pariwisata bahari yang berbasis kemasyarakatan dan meningkatkan promosi serta publikasi informasi. Penelitian santi tidak terfokus kepada manfaat yang dirasakan oleh masyarakat nelayan, karena masyarakat dalam penelitian Santi merupakan masyarakat yang tidak hanya berfrofesi sebagai nelayan. Duran (2010) lebih memfokuskan penelitiannya pada potensi yang dimiliki oleh daerah pesisir untuk dikembangkan sehingga memberikan manfaat kepada masyarakat. Musaddun dkk. (2013) menitik beratkan penelitiannya kepada pengembangan pariwisata pesisir dengan konsep keberlanjutan. Penelitian ini memiliki kesamaan dengan penelitian yang dilakukan oleh Santi (2017), Duran (2010) dan Musaddun dkk. (2013) dimana penelitian ini sama-sama meneliti di daerah pesisir dengan memberikan gambaran mengenai bentuk pengembangan yang akan dilakukan dengan memanfaatkan potensi yang dimiliki. Penelitian ini bertujuan untuk mengembangkan potensi daerah pesisir namun lebih mengutamakan pemberdayaan masyarakat nelayan. Karena selama ini dalam pengembangan daerah pesisir, nelayan hanya dijadikan sebagai daya tarik. Penelitian ini juga akan mengkaji bagaimana bentuk pengembangan daerah pesisir dengan melibatkan peran serta masyarakat nelayan.

\section{Tinjauan Teoritis \\ Teori Pengembangan}

Pengembangan adalah suatu proses atau cara menjadikan sesuatu menjadi maju, baik, sempurna, dan berguna (Suwantoro, 1997: 88-89). Suwantoro (1997:74) menyebutkan beberapa bentuk produk pariwisata alternatif yang berpotensi untuk dikembangkan, yaitu: Pari-wisata budaya (cultural tourism), ekowisata (eco-tourism), pariwisata bahari (marine tourism), pariwisata petualangan (adventure tourism), pariwisata agro (agrotourism), pariwisata perdesaan (village 
tourism), gastronomi (culinary tourism), pariwisata spiritual (spiritual tourism) dan lainnya.

Dalam perencanaannya pengembangan daya tarik wisata harus memperhatikan lima tahap proses peren-canaan pariwisata yaitu melakukan inventarisasi mengenai semua fasilitas yang tersedia dan potensi yang dimiliki, menaksir pasaran pariwisata dan mencoba melakukan proyeksi arus kedatangan wisatawan pada masa yang akan dating, memperhatikan di mana terdapat permintaan yang lebih besar dari pada persediaan atau penawaran, melakukan penelitian kemungkinan perlu-nya penanaman modal baik negeri maupun asing, melakukan perlindungan terha-dap kekayaan alam yang dimiliki dan memelihara warisan budaya bangsa serta adat istiadat suatu bangsa yang ada.

\section{Kawasan Pesisir}

Wilayah pesisir merupakan pertemuan antara daratan dan laut ke arah darat. Wilayah pesisir meliputi bagian daratan, baik kering maupun terendam air, yang masih dipengaruhi oleh sifat-sifat laut seperti pasang surut, angin laut dan rembesan air asin. Sedangkan ke arah laut wilayah pesisir mencakup bagian laut yang masih dipengaruhi oleh proses alami yang terjadi di darat seperti sedimentasi, aliran air tawar, maupun akibat kegiatan manusia di darat seperti penggundulan hutan dan pencemaran.

Batasan wilayah pesisir ke arah daratan mencakup wilayah administrasi daratan dan kearah perairan laut sejauh 12 mil laut diukur dari garis pantai ke arah laut lepas dan/atau kearah perairan kepulauan (UURI Nomor 27 Tahun 2007). Ekosistem wilayah pesisir dan lautan dipandang dari dimensi ekologi memiliki empat fungsi bagi kehidupan manusia yaitu sebagai penyedia sumberdaya alam, penerima limbah, penyedia jasa pendukung kehidupan manusia dan penyedia jasa kenyamanan (Bengen 2000).

Masyarakat pesisir merupakan kelompok orang yang tinggal di daerah pesisir dan bergantung secara langsung pada pemanfaatan sumberdaya laut dan pesisir untuk keberlangsungan hidup. Yang termasuk kedalam masyarakat pesisir antaralain nelayan, buruh nelayan, pembudidaya organisme laut, pedagang dan pengolah hasil tangkap laut, penjual jasa pariwisata dan transportasi, penjual cinderamata serta kelompok masyarakat yang memanfaatkan sumberdaya non-hayati laut dan pesisir untuk kebutuhan hidup seharihari (Nikijuluw 2001).

\section{Pemberdayaan Masyarakat}

Konsep pemberdayaan berkaitan dengan dua istilah yang saling bertentangan, yaitu konsep berdaya dan tidak berdaya terutama bila dikaitkan dengan kemampuan mengakses dan menguasai potensi dan sumber kesejahteraan social. Pemberdayaan masyarakat sebenarnya mengacu pada kata empowerment, yaitu sebagai upaya untuk mengaktualisasikan potensi yang sudah dimiliki masyarakat. 
Pemberdayaan

masyarakat

merupakan suatu proses atau cara untuk meningkatkan taraf hidup atau kualitas masyarakat. Harry Hikmat menyatakan ada tiga strategi utama pemberdayaan yaitu: tradisional, aksi langsung, dan transformasi (2010, 19). Ketiga strategi tersebut cendrung dilakukan secara terpadu, melalui tiga aras pemberdayaan yaitu aras mikro, mezzo dan makro (Suharto, 2005, 66-67). Melalui suatu kegiatan tertentu, yaitu melakukan kegiatan yang bertujuan meningkatkan kualitas SDM, yang disesuaikan dengan keadaan dan karakteristik di masyarakat itu sendiri. Pemberdayaan berasal dari kata dasar daya yang berarti tenaga, upaya, kemampuan melakukan sesuatu atau kemampuan bertindak. Selain itu pemberdayaan juga berasal dari bahsa inggris "empower" yang menurut Merriam Webster dan Oxford English Dictionary mengandung dua pengertian. Yang pertama adalah to give power or authority to/ memberi kekuasaan, mengalihkan kekuatan, atau mendelegasikan otoritas kepihak lain, sedangkan pengertian yang kedua yaitu to give ability to or enable/ upaya untuk memberi kemampuan atau keberdayaan (Teguh S, 2004: 28).

\section{Teori Nelayan}

Nelayan adalah orang yang hidup dari mata pencaharian hasil laut. Di Indonesia para nelayan biasanya bermukin di daerah pinggir pantai atau pesisir laut. Komunitas nelayan adalah kelompok orang yang bermata pencaharian hasil laut dan tinggal didesa-desa atau pesisir (Sastrawidjaya. 2002).

Memberikan definisi terhadap nelayan bukanlah merupakan pekerjaan yang mudah mengingat ada beberapa aspek yang harus diperhatikan, seperti apakah definisi nelayan tersebut mengacu kepada pekerjaan, tempat tinggal ataupun status pekerjaan.1 Pengertian nelayan menurut Kamus Besar Bahasa Indonesia (KBBI) adalah orang atau masyarakat yang mata pencarian utamanya adalah menangkap ikan, 2 sedangkan menurut Pasal 1 angka 10 UndangUndang No.31 Tahun 2004 tentang Perikanan, nelayan didefinisikan sebagai orang yang mata pencariannya melakukan penangkapan ikan. Pengertian nelayan menurut Mulyadi (2005) adalah sekelompok orang/masyarakat yang memiliki kemampuan serta sumber kehidupan di sekitar pantai/pesisir, dimana sumber penghasilan utamanya berkaitan erat dengan sektor perikanan dan perairan (laut dan sungai).

\section{METODE}

Dalam hal pengumpulan data ini digunakan metode studi kepustakaan, observasi dan wawancara. Instrumen penelitian yang dipergunakan dalam penelitian ini berupa pedoman wawancara yang dibuat oleh peneliti. Sugiyono (2014, hIm. 92) menyatakan bahwa "Instrumen penelitian adalah suatu alat pengumpul data yang digunakan untuk mengukur fenomena 
alam maupun sosial yang diamati". Sedangkan metode analisis data yang dipergunakan dalam penelitian ini adalah metode deskriptif kualitatif yang diperoleh dengan menganalisis data terlebih dahulu sebelum dideskripsikan.

\section{HASIL DAN PEMBAHASAN}

Desa Kuta merupakan salah satu desa di Kabupaten Badung yang mengembangkan sektor pariwisata sebagai roda penggerak perekonomian masyarakat Kuta. Hal ini tidak terlepas dari Kuta sebagai salah satu kawasan wisata di Bali. Sebagai salah satu kawasan wisata di Bali, perkembangan pariwisata di Desa Kuta mengalami kemajuan yang sangat pesat. Kemajuan pembangunan di bidang pariwisata ini dapat dilihat dari makin meningkatnya jumlah akomodasi dan fasilitas pariwisata yang dibangun di Desa Kuta. Hampir sebagian besar wilayah Desa Kuta terdapat fasilitas akomodasi atupun fasilitas pariwisata lainnya seperti restoran, spa dan sarana perbelanjaan. Perkembangan pariwisata ini tentunya memberikan dampak yang positif bagi perekonomian masyarakat di Desa Kuta.

Sebagai salah satu desa yang terletak di daerah pesisir, Desa Kuta menjadikan daerah pesisirnya sebagai sentra pengembangan pariwisata. Berbagai atraksi wisata dikembangkan untuk dijadikan sebagai daya tarik untuk menarik minat kunjungan wisatawan. Salah satunya adalah mengembangkan aktifitas wisata surfing/berselancar, dimana aktifitas wisata ini didukung oleh kondisi Pantai Kuta yang memiliki ombak sepanjang tahun dengan intensitas ketinggian ombak yang berbedabeda. Selain mengembangkan aktifitas surfing, pengembangan pariwisata di Desa
Kuta khususnya daerah pesisir dapat dilihat dari makin banyaknya jumlah akomodasi dan fasilitas pariwisata lainnya yang dibangun di sepanjang daerah pesisir Desa Kuta.

Perkembangan pariwisata di kawasan pesisir Desa Kuta yang begitu pesatnya tentunya tidak hanya memberikan dampak positif, akan tetapi juga akan menimbulkan dampak negatif. Salah satu dampak negatif yang muncul sebagai akibat dari pengembangan pariwisata di daerah pesisir Desa Kuta adalah semakin terdesaknya kehidupan masyarakat nelayan. Hal ini dapat kita lihat dari semakin berkurangnya aktifitas masyarakat nelayan di dalam melakukan aktifitasnya sehari-hari seperti melakukan aktifitas menangkap ikan. Selain itu semakin terdesaknya kehidupan masyarakat nelayan dapat kita lihat dari makin berkuranynya area yang diperuntukkan bagi aktifitas nelayan di pesisir Pantai Kuta.

Area pesisir yang sebelumnya diperuntukkan bagi aktifitas nelayan telah diambil alih oleh pembangunan Hotel atau fasilitas pariwisata lainnya. Jika hal ini terus dibiarkan maka eksistensi masyarakat nelayan di daerah pesisir Pantai Kuta akan semakin berkurang dan kemungkinan mengalami kepunahan. Tentunya jika hal ini sampai terjadi akan sangat disayangkan mengingat masyarakat nelayan merupakan Local Genius daerah pesisir yang perlu dilestarikan keberadaannya. Untuk itu perlu dilakukan suatu upaya untuk mensinergikan antara pengembangan pariwisata dengan keberadaan masyarakat nelayan di kawasan pesisir Desa Kuta. Salah satu upaya yang bisa dilakukan untuk mensinergikan antara pariwisata dan masyarakat nelayan adalah dengan cara mengembangkan konsep Desa Wisata di kawasan pesisir Desa kuta dengan memberdayakan masyarakat nelayan. 


\section{Pemberdayaan Masyarakat Nelayan dalam pengembangan Kawasan Pesisir di Kabupaten Badung}

Dalam Pengembangan Kawasan Pesisir ada tiga strategi utama yang bisa dilakukan di dalam pemberdayaan masyarakat nelayan yaitu: tradisional, aksi langsung, dan transformasi. Pengembangan Kawasan Pesisir tentunya sangat memerlukan peran serta masyarakat lokal didalam pengelolaannya. Hal ini mengingat bahwa pariwisata daerah pesisir merupakan kegiatan yang menawarkan warisan, seni, alam, kesehatan, pendidikan, olahraga, petualangan, kegiatan pertanian, dan minat yang terletak di daerah tujuan (Bramwell \& Lane, 1994). Bramwell \& Lane (1994) menjelaskan bahwa aktifitas yang ditawarkan oleh daerah tujuan adalah aktifitas yang memang dilakukan oleh masyarakat di desa tersebut secara turun temurun. Aktifitas tersebut tentunya dipengaruhi oleh tradisi dan kebudayaan yang berkembang dan asli dimiliki oleh masyarakat setempat. Jika melihat pernyataan tersebut sudah selayaknya bahwa pengembangan Kawasan Pesisir di Kabupaten Badung harus mengembangkan aktifitas atau budaya yang menjadi tradisi di daerah tersebut. Karena merupakan daerah pesisir maka aktifitas utama masyarakat di Kawasan Pesisir Kabupaten Badung yang telah dilaksanakan secara turun temurun salah satunya adalah aktifitas nelayan.

Menurut (Sastrawidjaya, 2002) komunitas nelayan adalah kelompok orang yang bermata pencaharian hasil laut dan tinggal didesa-desa atau pesisir. Masyarakat nelayan di Kawasan Pesisir Kabupaten Badung yang dimaksud dalam penelitian ini adalah masyarakat yang kegiatan sehariharinya adalah memperoleh hasil dari laut. Biasanya mereka melakukan kegiatan menangkap ikan. Kegiatan menangkap ikan ini dilakukan masyarakat nelayan untuk memenuhi kebutuhan sehari-hari. Kelebihan dari hasil tangkapan ikan barulah mereka jual ke pasar atau kepada para pembeli yang datang langsung ke pesisir. Kelompok masyarakat nelayan di Kawasan Pesisir Kabupaten Badung di koordinir oleh kelompok-kelompok nelayan yang tersebar di Kawasan Pesisir Kabupaten Badung. Menurut informasi yang diperoleh dari para nelayan, kegiatan nelayan di Kawasan Peisisir Kabupaten Badung sekarang ini lebih dominan mengantarkan wisatawan yang akan melakukan kegiatan berselancar/surfing. Sambil menunggu wisatawan selesai melakukan aktifitas surfing, para nelayan melakukan kegiatan menangkap ikan dengan cara mengail/memancing ikan. Kecuali pada musim ikan barulah mereka akan fokus untuk melakukan penangkapan ikan. Dalam kegiatan menangkap ikan, masyarakat nelayan di Kawasan Pesisir Kabupaten Badung masih berpatokan pada ilmu perbintangan. Tradisi ini mereka tetap jalankan karena merupakan warisan dari generasi terdahulunya. Masyarakat nelayan menginginkan tradisi ini tetap bisa dijaga kelestariannya sebagai sebuah pengetahuan yang merupakan ciri khas dari masyarakat nelayan itu sendiri.

Pemberdayaan masyarakat nelayan di Kawasan Pesisir Kabupaten Badung dilakukan dengan strategi sebagai berikut:

1. Tradisional

Dalam strategi pemberdayaan masyarakat nelayan ini, masyarakat akan melaksanakan kegiatan menangkap ikan dengan cara tradisional yang telah diwariskan secara turun-temurun. Penggunaan ilmu perbintangan dan penggunaan jukung/perahu tradisional merupakan salah satu cara masyarakat 
nelayan mempertahankan tradisi nelayan tradisional. Dalam proses menangkap ikan pun seperti upacara sebelum berangkat melaut ataupun setelah pulang dari melaut tetap mereka pertahankan sebagai wujud sistem kepercayaan yang mereka anut. Halhal yang bersifat tabu dalam proses penangkapan ikan masih mereka jalankan seperti tidak diperbolehkannya seorang wanita untuk ikut menangkap ikan. Dalam strategi pemberdayaan masyarakat nelayan ini, semua kegiatan yang telah menjadi tradisi akan dipertahankan dan dikemas menjadi atraksi wisata yang akan ditawarkan kepada wisatawan dengan memberdayakan masyarakat nelayan setempat.

\section{Aksi Langsung}

Aktifitas atau kegiatan wisata yang ditawarkan dalam strategi ini menuntut para wisatawan untuk terlibat didalam kegiatan penangkapan ikan secara tradisional. Wisatawan akan diajarkan bagaimana cara menangkap ikan secara tradisional mulai dari tahap persiapan sampai dengan tradisi yang dilakukan pada saat selesai melakukan kegiatan menangkap ikan. Tentunya kegiatan melibatkan wisatawan secara langsung ini akan memberikan pengalaman yang menarik bagi para wisatawan. Dalam prosesnya kegiatan ini tidak menemui kendala yang berarti terutama dalam kegiatan berkomunikasi, karena dalam kesehariannya para nelayan sudah sering berinteraksi langsung dengan para wisatawan, sehingga penggunaan bahasa asing dalam kegiatan komunikasi tidak lagi menjadi penghambat bagi para nelayan didalam berinteraksi dengan wisatawan.

\section{Transformasi}

Dalam proses menangkap ikan yang ditawarkan sebagai atraksi wisata, secara tidak langsung akan terjadi proses transformasi baik dari segi informasi ataupun budaya nelayan dari masyarakat nelayan kepada para wisatawan. Dengan melibatkan secara langsung para nelayan dalam kegiatan ini, proses transformasi akan berjalan dengan baik. Wisatawan pun akan mudah memahami mengenai kegiatan nelayan, karena para wisatawan langsung dibimbing oleh para nelayan tersebut.

\section{Dampak ekonomi yang ditimbulkan bagi masyarakat nelayan didalam pengembangan daerah pesisir dengan pemberdayaan masyarakat nelayan di Kabupaten Badung}

Dampak ekonomi didefinisikan sebagai biaya langsung dan manfaat perjalanan dalam industri perjalanan (Frechtling, 1994). Selain itu, dampak ekonomi dijelaskan sebagai perubahan kehidupan ekonomi masyarakat lokal yang dihasilkan dari pengeluaran yang dikaitkan ke suatu acara atau fasilitas (Turco dan Kelsey, 1992). Penciptaan lapangan kerja, peluang wirausaha, daya tarik investasi besar dan kontribusi, adalah contoh dampak ekonomi yang mengarah pada peningkatan posisi ekonomi dan kehidupan yang lebih baik di daerah tujuan (Akis et al., 1996). Menurut (Walpole dan Godwin, 2000), pariwisata adalah alat untuk pembangunan ekonomi. Masyarakat lokal mendukung pengembangan pariwisata sebagai kegiatan pariwisata yang akan mengarah pada pembangunan ekonomi seperti memberikan peluang investasi dan sebagai sumber baru untuk menghasilkan pendapatan (Gursoy dan Rutherford, 2004). Penelitian sebelumnya melaporkan hubungan positif dan signifikan antara manfaat ekonomi yang dirasakan dan sikap terhadap pengembangan pariwisata (Jurowski et al., 1997).

Studi sebelumnya juga menunjukkan bahwa ada hubungan yang signifikan dan positif 
antara daya saing tujuan dan dampak ekonomi dari pengembangan pariwisata (Yoon, 2002). Pengembangan desa wisata daerah pesisir dengan pemberdayaan masyarakat nelayan di Kabupaten Badung akan memberikan dampak yang positif terhadap perekonomian masyarakat nelayan. Hal ini nantinya akan bisa dilihat secara langsung karena didalam pengembangannya masyarakat nelayan akan dilibatkan secara langsung mulai dari tahapan perencanaan sampai dengan pelaksanaan Dengan melibatan masyarakat secara langsung, diharapkan masyarakat nelayan bisa memperoleh maanfaatnya secara langsung terutama dilihat dari sisi ekonomi. Aktifitas yang ditawarkan seperti mengantarkan wisatawan yang berkeinginan untuk melakukan kegiatan menangkap ikan serta mengantarkan wisatawan untuk melaksanakan aktifitas lainnya di tengah laut dan diharapkan akan memberikan dampak ekonomi secara langsung kepada masyarakat nelayan.

\section{Dampak sosial budaya yang ditimbulkan bagi masyarakat nelayan didalam pengembangan daerah pesisir dengan pemberdayaan masyarakat nelayan di Kabupaten Badung}

Fredline dkk, (2003) mendefinisikan dampak sosial sebagai implikasi yang dapat memengaruhi kualitas kehidupan penduduk setempat. Ap dan Crompton (1998) menjelaskan dampak sosial-budaya yang positif seperti meningkatkan standar hidup, infrastruktur atau fasilitas dari tujuan pengembangan pariwisata, perlindungan umum, meningkatkan hubungan dan pemahaman terhadap budaya, tradisi, warisan, identitas, nilai-nilai yang berbeda antara pengunjung dan masyarakat lokal.
Para peneliti telah menunjukkan bahwa masyarakat akan lebih mungkin untuk mendukung pengembangan pariwisata jika mereka menerima manfaat dari pengembangan pariwisata, seperti pertukaran budaya dan identitas budaya (Chen dan Gursoy, 2001). Masyarakat lokal memandang pariwisata sebagai penyedia berbagai manfaat sosio-budaya (Sirakaya et al., 2002; Besculides dan McCormick 2002). Masyarakat lokal mendapatkan kesempatan untuk berinteraksi secara langsung dengan orang-orang dari berbagai latar belakang melalui kegiatan pariwisata, memperluas pola pikir mereka dan meningkatkan kebanggaan dan semangat mereka melalui upacara tradisional (Kreag, 2001). Pengembangan desa wisata daerah pesisir dengan pemberdayaan masyarakat nelayan di Kawasan Pesisir Kabupaten Badung akan memberikan dampak yang positif terhadap sosial budaya masyarakat nelayan. Dengan interaksi langsung dengan para wisatawan, masyarakat nelayan akan memperoleh pengetahuan mengenai kehidupan sosial, kebiasaan ataupun tradisi yang dimiliki oleh para wisatawan. Secara tidak langsung masyarakat nelayan juga bisa mempelajari kebudayaan yang di anut para wisatawan, seperti sistem teknologi ataupun mengenai penggunaan teknologi dalam budaya modern yang dianut oleh para wisatawan. Disisi lain tradisi yang telah dijalankan secara turun-temurun oleh masyarakat nelayan di kawasan pesisir masih terjaga dan bisa dilestarikan untuk generasi berikutnya.

\section{PENUTUP}

Pengembangan daerah pesisir dengan pemberdayaan masyarakat nelayan di Kawasan Pesisir Kabupaten Badung, 
merupakan salah satu bentuk pengembangan kawasan pesisir yang bertujuan agar masyarakat nelayan sebagai local genius daerah pesisir bisa memperoleh secara langsung manfaat dari pengembangan kepariwisataan di daerahnya. Model pemberdayaan masyarakat nelayan yang dikembangkan dalam pengembangan kawasan pesisir ini menggunakan beberapa strategi tradisional yaitu, aksi langsung, dan transformasi. Pengembangan daerah pesisir dengan pemberdayaan masyarakat nelayan diharapkan mampu memberikan dampak positif terhadap perekonomian dan sosial budaya masyarakat nelayan. Dampak ekonomi dapat dilihat dari pendapat langsung yang diterima masyarakat nelayan dari keterlibatan mereka secara langsung dalam pengembangan daerah pesisir, sedangkan dampak sosial budaya yang dirasakan masyarakat nelayan diperoleh dari interaksi langsung dengan para wisatawan, seperti misalnya masyarakat nelayan mengetahui kebiasaan-kebiasaan wisatawan, pemanfaatan teknologi dan kemampuan berkomunikasi dengan menggunakan bahasa asing.

\section{DAFTAR RUJUKAN}

Anggayana, I. W. A., \& Sari, N. L. K. J. P. (2018). Kemampuan Berbicara Bahasa Inggris Mahasiswa Akomodasi Perhotelan: sebuah Kajian Fonologi. Jurnal Manajemen Pelayanan Hotel, 1(1), 8-14.

ANGGAYANA, I. W. A., NITIASIH, D. P. K., BUDASI, D. I. G., \& APPLIN, M. E. D. (2016). Developing English For
Specific Purposes Course Materials for Art Shop Attendants and Street Vendors. Jurnal Pendidikan Bahasa Inggris Indonesia, 4(1).

Akis, S., Peristianis, N. and Warner, J. (1996), 'Residents' attitudes to tourism development: the case of Cyprus", Tourism Management, Vol. 17 No. 7, pp. 481-494.

Ap, J. and Crompton, J.L. (1998), "Developing and Testing a Tourism Impact Scale", Journal of Travel Research, Vol. 37 No. 2, pp. 120-130.

Bengen DG. 2000. Sinopsis Ekosistem dan Sumberdaya Alam Pesisir. Bogor (ID): Pusat Kajian Sumberdaya Pesisir dan Lautan IPB

Bramwell, B. and B. Lane., (1994), "Rural Tourism and Sustainable Rural Development”, pp. 129. Clevedon: Channel View Publications.

Frechtling, Douglas C. (1994). "Assessing the Economic Impacts of Travel and Tourism -Introduction to Travel Economic Impact Estimation" Travel, Tourism and Hospitality Research: A Handbook for Managers and Researchers, Chapter 31, 2nd edition, John Wiley \& Sons, New York.

Gursoy, D., Jurowski, C. and Uysal, M. (2002), "Resident attitudes - a structural modeling 
Approach",Annals of Tourism

Research, Vol. 29 No.1, pp. 79-105.

Harry, Hikmat, 2010, Strategi

Pemberdayaan Masyarakat.

Bandung: Humaniora Utama Press

Jurowski, C., Uysal, M. and Williams, D.R. (1997), “A Theoretical Analysis of Host Community Resident Reactions to Tourism", Journal of Travel Research, Vol. 36 No. 2, pp. 3-11.

Kreag, G. (2001), "The impacts of tourism", Minnesota Sea grant. Retrieved from: http://www.seagrant.umn.edu/touris $\mathrm{m} /$ pdfs/ImpactsTourism.pdf.

Mulyadi. S, 2005, Ekonomi Kelautan, PT Grafindo Persada, Jakart

Musaddun, dkk.2013. Bentuk Pengembangan Pariwisata Pesisir Berkelanjutan di Kabupaten Pekalongan. Jurnal Ruang Vol 1.No.2. ISSN No.1858 3881

Nikijuluw V. 2001. Populasi dan Sosial Ekonomi Masyarakat Pesisir serta Strategi Pemberdayaan Mereka Dalam Konteks Pengelolaan Sumberdaya Pesisir Secara Terpadu. Prosiding Pelatihan Pengelolaan Wilayah Pesisir Terpadu hal 14-27. 29 Oktober-3 November 2001. Bogor (ID)

Sirakaya, E., Teye, V. and Sonmez, S. (2002), 'Under standing residents' support for tourism development in the central region of Ghana", Journal of Travel Research, Vol. 40, pp. 151155.

Suharto,Edi.2005. Membangun Masyarakat Memberdayakan Rakyat. Bandung : Aditama

Santi, Ni Made, 2017."Kajian Wisata Bahari Terhadap Kesejahteraan Masyarakat di Kawasan Pesisir Pulau Nusa Penida Provinsi Bali”.Bogor : Institut Pertanian Bogor

Walpole, M.J. and Goodwin, H.J. (2000), "Local Economic Impacts of Dragon Tourism in Indonesia",Annals of Tourism Research, Vol. 27 No. 3, pp. 559-576.

Yoon, Y. (2002), "Development of a structural model for tourism destination competitiveness from stakeholders' perspectives", Unpublished Doctoral Dissertation, The Virginia Polytechnic Institute and State University-Blacksburg. Retrieved from https://theses.lib.vt.edu/theses/availa ble/etd1003200265524/unrestricted/Touris mDestinationCompetitivenessYooshi kYoon.pdf 